\title{
Preface
}

\section{Jill Vickers}

Why is this Handbook important to both federalism scholars and feminist political scientists (FPS)? Its first objective is to introduce the rich and fast-growing literature about how state architectures interact with various categories of difference, 'gender' but also 'race', faith, ethnic or sexual minorities, etc. The Handbook's second objective is to encourage both federalism scholars and FPS to explore how such categories interact and how they affect and are affected by colonialism, decolonization, military or authoritarian governments and their aftermaths. A third objective is to build theoretical bridges between research about older, 'Western' federations established before democratization and about post-colonial federations in the global south, in many of which federalism was imposed by the colonial power. The Handbook is important because it highlights new, insightful research about relations between territorial and non-territorial differences and about how federations manage conflicts that result from various forms of territorial pluralism. This makes the Handbook a 'must-read' not least because it reveals how state architectures shape how marginalized groups - including women's movements - organize politically in federations and engage with central and regional governments.

Earlier waves of researchers focused on 'gender and federalism', but many contributors to this Handbook use expanded categories of 'difference' and new research about federations in the global south. Some employ intersectional approaches that show how multiple, intersecting categories of difference affect policy development. Few contributors pay attention to the debates about the origins of intersectionality (Hancock 2016), but instead use intersectional approaches to explore conflicts between group rights in federations (see Peter (Jay) Smith's exploration of conflicts between the rights of women and religious minorities in Canada and Nigeria in Chapter 4). Therefore, use of an 'intersectional lens' can reveal much about conflict management, especially in post-colonial federations. Those using intersectional approaches usually focus on local issues in federations in the global north (Patil 2013, 853), but some contributors theorize how systems of 'race', class, ethnicity, nation, sexuality and especially 'gender' serve as 'mutually constructing features of social organization' (Hancock 2016, 32) and focus on post-colonial federations in the global south. By observing how categories of difference interact in federations, they engage with diversity in meaningful ways. Some federalism scholars (e.g. Miller 2008; Vickers and Isaac 2012) show how state architectures shape marginalized groups' representation, affect their opportunities for democratic participation and structure the environments within which they make policies (Miller 2008, vi). Traditionally, studies of federalism have focused on ethnicity and language, but scholars of federalism and race (e.g. Miller 2008) have led some contributors to expand the categories of difference studied and to include the effects of previous colonialism, slavery and military or authoritarian rule.

Studies of federalism are multidisciplinary but the participating disciplines have biases that may obscure how state architectures affect categories of difference. One such bias is methodological nationalism - the belief that the unitary nation-state is the modern world's natural political form or the proper 'container' for modern politics and so a 'given' in political, legal and policy analysis. This led most political scientists - including FPS - to ignore state architectures, regional governments and interactions in studying categories of difference 
including 'gender'. But some Handbook contributors show how 'gender' and other differences can be incorporated into both federalism studies and comparative politics. They also want to persuade FPS and feminist legal scholars of the value of institutionalism, especially feminist institutionalism in theorizing interactions among colonialism, development, federalization and democratization. Another problem is the belief that federalism studies are a minor academic specialty given the few federations compared to unitary nation-states. But Watts (2008, xii) established that at least 40 per cent of the world's population live in federations, while many more experience multilevel governance and various 'federal arrangements'.

Globally, seven of the world's eight largest countries are federations and federalization is associated with struggles for democracy in 'hot-spots' like Hong Kong, Catalonia, Kashmir, Venezuela and Brazil. But the lack of accessible data about regional governments is another barrier. The editors hope the Handbook's demonstration of the importance of regional governments in establishing full citizenship for women and other marginalized groups will persuade agencies like the Inter-Parliamentary Union and United Nations Women to collect systematic regional information for their databases. Nonetheless, the Handbook is a 'must-read' even in the absence of such data, because many contributions reveal how colonialism, decolonization, military or authoritarian governance and decentralization affect interactions between federalization and democratization. While most social scientists and political activists assume democratization and decentralization have positive effects for women's rights and citizenship, recent studies of their effects in Indonesia suggest more complex interactions and outcomes. Nur Hidayah (2019), for example, found that in largely Muslim regions of Indonesia, informal federalization and democratization legitimized regulations that reduced women's rights and citizenship and constrained their lives. Future research should establish if such outcomes result from informal federalization or from federal decentralization generally.

Most theoretical approaches treat federations as if they were unitary states, assuming that their central governments can always 'trump' their regional counterparts, thereby making them irrelevant. But regional governments significantly increase the number of legislatures in which decisions are made and the number of offices to which women and others in categories of difference can be elected or appointed. As more countries devolve powers to regional governments or adopt even partial 'federal arrangements', federalism's importance increases. Moreover, 'federalism' isn't static, but changes as power is devolved to regional governments or with the neoliberal 'offloading' of responsibilities to non-government actors. Further, while 'what is within the scope of “the national" has enlarged over time' (Irving 2008, 68), 'traditional female spheres of education, health, welfare and family matters are far less commonly represented, if at all, in "the... national"” (Vickers 2017, 167). This makes regional policy-making especially important for women and other marginalized and diverse groups.

In earlier research, a key theme was 'how... political architecture... affected women's citizenship and whether women were active participants in its design' (Haussman et al. 2010, 17). By expanding the meanings of 'diversity', contributors to this Handbook relate them to different patterns of federalization and democratization. Indeed, the extensive theorizing about such relations is its most valuable contribution to federalism scholarship and feminist political and legal studies. The Handbook's inclusion of research about both post-colonial and Western federations makes it possible to understand how the effects of federal architectures change over time and differ according to context. 


\section{REFERENCES}

Hancock, Ange-Marie (2016), Intersectionality: An Intellectual History, New York: Oxford University Press.

Haussman, Melissa, Marian Sawer and Jill Vickers (2010), Federalism, Feminism and Multilevel Governance, Farnham: Ashgate.

Hidayah, Nur (2019), 'Islamic Law and Women's Rights in Indonesia: A Case of Regional Sharia Legislation', AHKAM, 19 (1), 19-38.

Irving, Helen (2008), Gender and the Constitution: Equity and Agency in Comparative Constitutional Design, New York: Cambridge University Press.

Miller, Lisa (2008), The Perils of Federalism: Race, Poverty and the Politics of Crime Control, New York: Oxford University Press.

Patil, Vrushali (2013), 'From Patriarchy to Intersectionality: A Transnational Assessment of How Far We've Really Come', Signs: Journal of Women in Culture and Society, 38 (4), 847-67.

Vickers, Jill (2017), 'Gendering Federal Constitutions', in Helen Irving (ed.), Constitutions and Gender, Cheltenham, UK and Northampton, MA, USA: Edward Elgar Publishing, 163-94.

Vickers, Jill and Annette Isaac (2012), The Politics of Race: Canada, the United States and Australia, $2^{\text {nd }}$ ed., Toronto, Buffalo: University of Toronto Press.

Watts, Ronald L. (2008), Preface, in Richard P. Chaykowski and Robert Hickey (eds), Comparing Federal Systems, 3rd ed., Kingston: Institute of Intergovernmental Relations, Queen's University, xiii. 